\title{
Estimating Carbon Emissions Avoided by Electricity Generation and Efficiency Projects: A Standardized Method (MAGPWR)
}

S. Meyers, C. Marnay, K. Schumacher, and J. Sathaye

\author{
Energy Analysis Department \\ Environmental Energy Technologies Division \\ Lawrence Berkeley National Laboratory \\ Berkeley, CA 94720 USA
}

\begin{abstract}
July 2000
Prepared for the U.S. Environmental Protection Agency

Climate Policy and Program Division

Office of Economics and Environment

Office of Policy, Planning and Evaluation
\end{abstract}




\begin{abstract}
This paper describes a standardized method for establishing a multi-project baseline for a power system. The method provides an approximation of the generating sources that are expected to operate on the margin in the future for a given electricity system. It is most suitable for smallscale electricity generation and electricity efficiency improvement projects. It allows estimation of one or more carbon emissions factors that represent the emissions avoided by projects, striking a balance between simplicity of use and the desire for accuracy in granting carbon credits.
\end{abstract}




\section{Introduction}

Estimation of the $\mathrm{CO}_{2}$ emissions that are avoided by projects that supply electricity to the grid or reduce electricity demand through efficiency improvement requires a baseline emissions rate that represents what would have happened if not for the project. Estimating the effect of projects hinges upon finding the type of power plants whose construction or use would be avoided by the projects, and the carbon emissions avoided by their reduced operation.

For joint implementation projects, baseline setting and determination of additionality has taken place on an ad hoc, case-by-case basis. This approach has required project developers to expend significant time and resources in preparing projects and moving them through a review process. In response to this situation, there has been interest in standardized methods for setting a baseline that could apply to all projects in a given sector and country.

Establishing a multi-project baseline for the power system would provide project developers with factors that they could use in calculating the carbon emissions expected to be avoided by a project, and the number of carbon credits claimed after the project has been underway. A multiproject baseline could be expressed in terms of $\mathrm{kg} \mathrm{C}$ per $\mathrm{kWh}$ avoided. All projects affecting the electricity system in a given country (or region in a country) would use the same values, and project developers would not have to make estimates on their own.

In thinking about how a project may affect a power system, there are two aspects to consider. Projects with relatively small impacts on the system can be viewed as affecting the operation of a system at the margin. Whether providing electricity supply or reducing demand through efficiency improvement, the effect is to reduce the load that the system must meet.

In contrast, projects that propose to supply large amounts of power may take the place of some other power plant that would have been built. A baseline for large projects could be projectspecific, or could reflect a multip project baseline based on a mix of planned new capacity or the dominant type of new capacity.

The method described in this paper is primarily intended for small-to-medium size projects that affect operation at the margin. However, the basic approach could also be used to model substitution of a large project power plant for a planned power plant that would otherwise be part of the system.

Although the power sector is complex, it is quite feasible to base a multi-project baseline on projected operation of the relevant system, which could be at a national or regional level. One option would be to rely on the simulation models that are routinely used by utility companies to plan for future capacity expansion. Various models used in generation planning (e.g., WASP) can estimate the specific power plants that would be operated in future years, and the most economically attractive operation of the system. For the purposes of setting an official multiproject baseline, however, a disadvantage is that this type of model requires considerable data and expertise to use, and is not transparent or easily reviewed. In addition, a utility company may not be a disinterested party with respect to how a multi-project baseline is set, since it may seek carbon credits for its own projects.

\footnotetext{
${ }^{1}$ For an in-depth discussion of alternative baseline approaches in the power sector, see Lazarus, M., S. Kartha, S. Bernow, Key Issues in Benchmark Baselines for the CDM, Tellus Institute, Boston, 2000.
} 
This paper describes a method - MAGPWR (Marginal Avoided GHG - Power) for establishing a multi-project baseline for a power system that strikes a balance between simplicity of use and the desire for accuracy in granting carbon credits. It requires a relatively small amount of data, and is easily understood by interested parties. It could be used by a national energy agency or an entity with specific responsibility for CDM or JI projects.

\section{Overview of the Method}

Small-scale electricity generation and electricity efficiency improvement projects both result in a reduction in the load that the electricity system needs to meet. The approach described here provides a method for estimating the types of electricity generation that are expected to be the marginal source during a given period. It provides a reasonable estimate of which source(s) are likely to be curtailed in response to the load reduction from projects.

The load of an electricity generation system during a given period can be represented in a diagram that plots system power output as a function of time (Figure 1). In order to clarify the respective roles of different power sources in meeting the load, chronological load data can be converted into a load duration curve (LDC). A load duration curve is a reordering of chronological load data into the form of Figure 2, in which the x-axis shows how many hours the load was equal to or greater than the power level shown on the y-axis. For each hour in the period, there is a particular cost-minimizing dispatch of power sources to meet the demand. The basic goal of the method is to approximate this dispatch, by filling in the area underneath the load duration curve, which represents the total energy requirement. In so doing, one can estimate which sources operate at the margin, and for how long.

Approximating the dispatch of the system requires some judgement. In normal operations, the sources with the lowest marginal cost are used as much as possible, while more expensive sources are used as needed. In actual operation, the dispatch does not conform to simple economic rules, but for purposes of approximation using such criteria is reasonable. If better information on system operation is known, it can be used. Cooperation with the system operator is advisable.

This method treats each power source as if it were a single homogenous unit. There is no attempt to depict the system operation with respect to dispatch of individual units ${ }^{3}$ The emission factor (EF) used for each type of generation would normally be the average value, unless there is good reason to use a different value.

Once one has filled in a LDC for a given period, deriving a factor for avoided carbon emissions is straightforward. If only one source is marginal for the entire period, the appropriate factor is simply the emissions factor for that source. If two or more sources are marginal, the factor is the average of the respective emission factors for each source, weighted by the percentage of hours in the period for which each source is marginal. This derivation will become clear in the examples described below.

It is simpler to construct an LDC based on projected operation than to try to depict what actually happened in a prior year. Looking retrospectively at a previous year, based on actual data, opens

\footnotetext{
2 "Dispatch" refers to the manner in which system operators use specific power plants.

${ }^{3}$ The carbon emitting characteristics of various fuels differ considerably, whereas the difference between plants burning the same fuels is less dramatic.
} 
the door to argument about how well the method's results reflect how the system actually operated. The farther in the future one projects, however, the more difficult it is to estimate the system's operation. The best approach would be to use the method to derive EFs on an annual basis.

The figures in the following section were created from an Excel-based spreadsheet. The steps in the process and the data required are described in the Appendix.

\section{Examples for Different Levels of System Complexity}

\section{Electricity System Without Significant Seasonal Variation}

Figure 3 depicts the operation of a hypothetical system with only two generating sources: hydropower and gas turbines. ${ }^{4}$ Since there is little seasonal variation in operation, one curve is adequate for the entire year. In this system, hydropower is of the run-of-river type and is used to meet the base load throughout the year. Gas turbines are dispatched whenever the hydropower is not sufficient to meet the load. It is clear that the hydro resource will always be used first because its variable operating cost is very low while that of the gas turbine is high. In other words, the hydro "fuel" is virtually free. In the case depicted, there is not a single hour in the year when hydropower is the marginal source. Even when the load is at its lowest level, a gas turbine is the marginal source.

Figure 4 depicts the operation of a more complex system with seven power sources. (The data in Figures 4, 7 and 8 are based on recent electricity generation statistics for Thailand.) The stacking of the various sources is based on their marginal cost of generation. The primary marginal sources are combined cycle and fuel oil thermal plants. The system emissions factor is the average of the respective EFs, weighted by the percentage of hours for which each source is marginal (see table below the figure for derivation of the EF).

\section{Electricity System With Significant Seasonal Variation}

In many cases where hydropower is significant, there is seasonal variability in the amount of hydro energy that is available. For such a system, it is desirable to construct separate load duration curves for the "wet" and "dry" seasons. Figure 5 depicts the operation of the two-source system during the wet season (assumed to be four months in this case), when more hydropower is available. For certain hours of the year, hydro is the marginal power source. In this case, the carbon EF for the wet season would be the average of the respective EFs, weighted by the percentage of hours for which each source is marginal.

Figure 6 depicts the operation during the dry season (eight months in this case), when less hydropower is available. In this period, hydro is never the marginal power source, so the EF is simply the EF for gas turbines.

Figure 7 and 8 depict the multiple-source system assuming that wet and dry seasons have different operating features. The wet season has more hydro generation than the dry season, with

\footnotetext{
${ }^{4}$ In the calculations in this report, we do not account for any emissions of methane that may be associated with hydro reservoirs.
} 
the result that the mixture of marginal sources is slightly different, and thus the EFs are also different.

\section{Accounting for Peak and Off-Peak Impacts}

If there are likely to be projects whose impacts on the power system are significantly different during peak and off-peak periods, ${ }^{1}$ it may be desirable to estimate separate LDCs for peak and off-peak periods of the day over a year or during a particular season. The approach is essentially similar to that involved in accounting for seasonal variation. It requires selecting the appropriate hours in a period that are considered peak and off-peak, and then estimating how the power sources are expected to be dispatched during the relevant period.

\section{Systems with Electricity Shortage}

If an electricity system is expected to be unable to meet demand due to insufficient capacity, some modification of the EF calculation procedure is necessary. For the sake of simplification, one can assume that the shortage occurs around the system's peak load (the left part of the load duration curve). A reduction in demand from a project during these hours does not reduce power plant operation, since the demand is unmet. The relevant period for calculation of the EF is the period when system is expected to meet the demand. A rough approximation is probably the best one could do. With the new load duration curve, the expected dispatch of generating resources may need to be adjusted.

\section{Use of Carbon Emissions Factors}

Creating more realism and complexity by deriving different EFs that are appropriate for different periods (on a seasonal and/or daily basis) requires a project sponsor to provide data on the electricity production or savings from the project in greater detail.

The EF(s) for an electricity system could be of two types. A short-run estimate (one year) could be used for calculations of the amount of carbon credits projects could claim for a given year. For example, the host country government could announce EFs at the beginning of each year based on current projections of the system's operation for that year. That EF would then be applied to the verified electricity generation or demand reduction accomplished by projects in that year.

A long-run estimate (10-15 years) could be used by project sponsors for estimating carbon emissions that may be avoided by projects during their lifetime. This would represent an official "best guess"- based on official plans if possible - that project sponsors could use for projecting potential revenue from carbon credits.

In a system for which only a single EF has been derived for a year, the use is simple. The sponsor would simply multiply the measured electricity generation or the monitored electricity savings (including avoided T\&D losses) by the given EF.

\footnotetext{
${ }^{5}$ An example would be a lighting efficiency project whose impacts occur mainly during the peak period.
} 
In a system for which separate EFs have been derived for different seasons, the sponsor would need to know or estimate the electricity generation or savings for each season, as shown in the table below.

Note that this method only accounts for avoided emissions from the power system. If the electricity generation project has carbon emissions, these must be subtracted from the avoided emissions from the power system to yield the net avoided emissions by the project.

\begin{tabular}{|l|c|l|l|}
\hline Season & $\begin{array}{l}\text { Generation } \\
\text { Or Savings } \\
\text { In Period } \\
(\mathrm{MWh})\end{array}$ & $\begin{array}{l}\text { Carbon } \\
\text { Emissions } \\
\text { Factor } \\
(\mathrm{kgC} / \mathrm{MWh})\end{array}$ & $\begin{array}{l}\text { Avoided } \\
\text { Carbon } \\
\text { Emissions } \\
(\mathrm{tC})\end{array}$ \\
\hline $\begin{array}{l}\text { Dry } \\
\text { (Nov-Feb) }\end{array}$ & 20,000 & 257 & 5,140 \\
\hline $\begin{array}{l}\text { Wet } \\
\text { (Mar-Oct) }\end{array}$ & 50,000 & 200 & 10,000 \\
\hline Annual Total & -- & -- & 15,240 \\
\hline
\end{tabular}

* Based on two-source system (Figures 5 and 6)

In a system for which separate EFs have been derived for peak and off-peak periods (with no seasonal variation), the sponsor would need to know or estimate the annual electricity generation or savings that took place during the peak and off-peak periods.

In a system for which separate EFs have been derived for peak and off-peak periods during different seasons, the sponsor would need to know or estimate the annual electricity generation or savings that took place during the peak and off-peak periods in each season. Providing this level of detail could be difficult for project sponsors. In a system with diverse generating assets and considerable variation in operation, however, such detail could be important for accurately characterizing avoided carbon emissions.

\section{Other Baselines for Electricity-Related Projects}

The proposed power system multi-project baseline would not obviate the need for an end-use baseline for electricity-saving projects. For example, if a project involved improvements in electric motor system efficiency in an industrial plant, there would need to be a baseline at the site level. Such a baseline could be either multi-project or project-specific.

A multi-project baseline system for energy efficiency projects could work in tandem with a power system multi-project baseline. A baseline at the end-use level would guide calculation of the electricity savings that would be eligible for credit. The power system EF would then allow conversion of the electricity savings into carbon units. Since most efficiency projects have relatively small impacts, the method described in this paper would be appropriate for deriving a multi-project baseline. 
The multi-project baseline EF would be applicable for a particular power grid. For off-grid projects that displace the use of remote power sources (usually a diesel generator), it would be possible to establish a default emissions factor that reflects the average value for either existing or new diesel generators in a country. As with the power system baseline, the emissions factor for diesel generators would be updated as appropriate.

\section{Conclusion}

The method described in this paper for estimating a multi-project baseline for an electricity system is able to provide a reasonable degree of accuracy with respect to how a given system would be affected by projects with small-to-medium size impacts on the load. The data and computation requirements are relatively modest. The method does involve some subjective judgement regarding the nature of a system's operation, but this judgement could be readily reviewed by independent experts. 


\section{Appendix:Steps in the Method}

\section{Step 1: Draw a Load Duration Curve}

- Data requirement: Chronological load data (typically in MW) for each hour of a year (or other period). For use in the spreadsheet, the load data need to be organized in a single column. If the load data are not in such a form, simple algorithms can be provided to perform such organization. This type of load data can usually be obtained from system operators.

- Sort load data (only) from highest to lowest MW level. Leave hourly data unchanged. Plot load data against hours of the period. Automatically performed by LBNL spreadsheet model.

Step 2: Organize Data on Generating Sources

- Data requirement: Available capacity and projected generation in year (or other period) by source.

\section{Step 3: Stack ("Dispatch") Sources to Meet the Load}

- Automatically performed by LBNL spreadsheet model. Model calculates how many hours a year (or other period) each source was active at an average capacity of $x y$ MW. Model determipes how many hours in a year (or other period) the non-baseload sources were at the margin.

\section{Step 4: Calculate Carbon Emissions Factor for the System for Relevant Period}

- Data Requirements: For each source, information on the type of fuel used, the conversion efficiency (in \%), the carbon content of the fuel used (in tC/TJ), and the combustion efficiency of this fuel (in \%).

- The model computes the Marginal Carbon Emissions Factor as the average of the respective emissions factors, weighted by the percentage of hours for which each source is marginal.

\footnotetext{
${ }^{6}$ The model algorithm advances in discrete steps (by the hour) starting at the last hour. Going backwards along the load curve, in each step it determines the area under the load curve for the relevant source subject to the total generation and available capacity constraints. It stops at the hour and capacity where the generation constraint is fulfilled and the available capacity is not exceeded. For baseload sources, the algorithm only calculates the average capacity usage given the information on total electricity generation from these sources.
} 


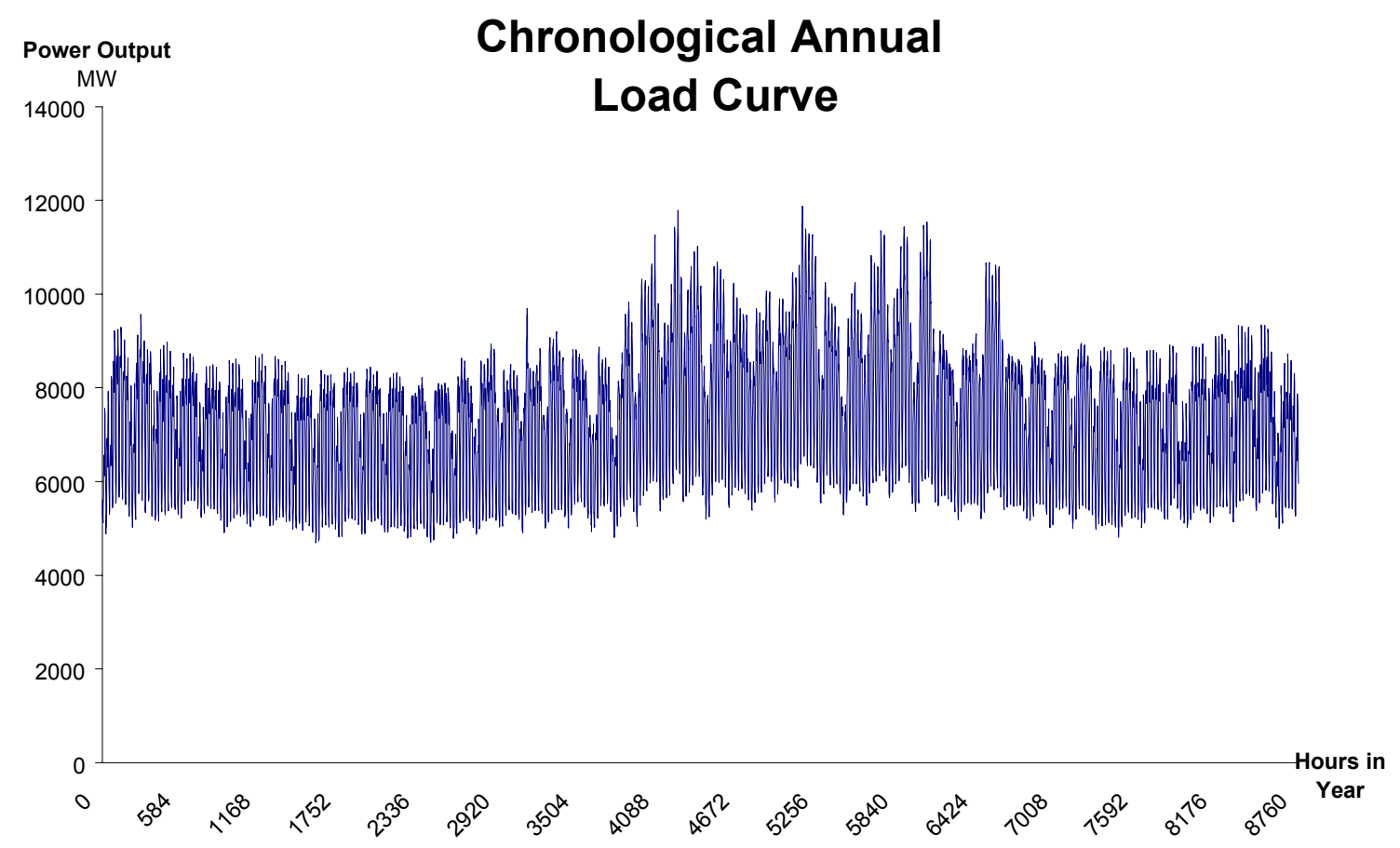

Figure 1 


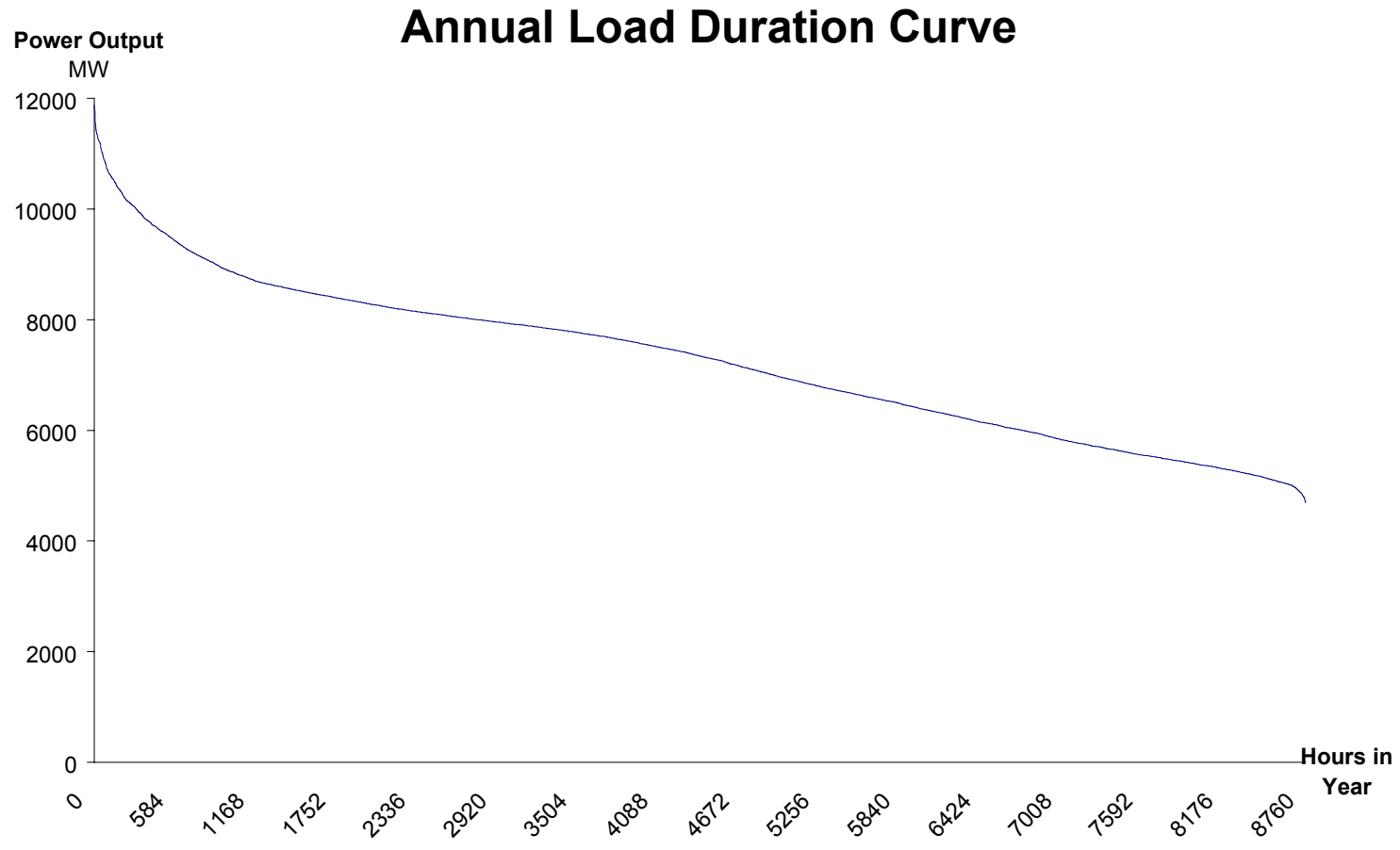

Figure 2

9 


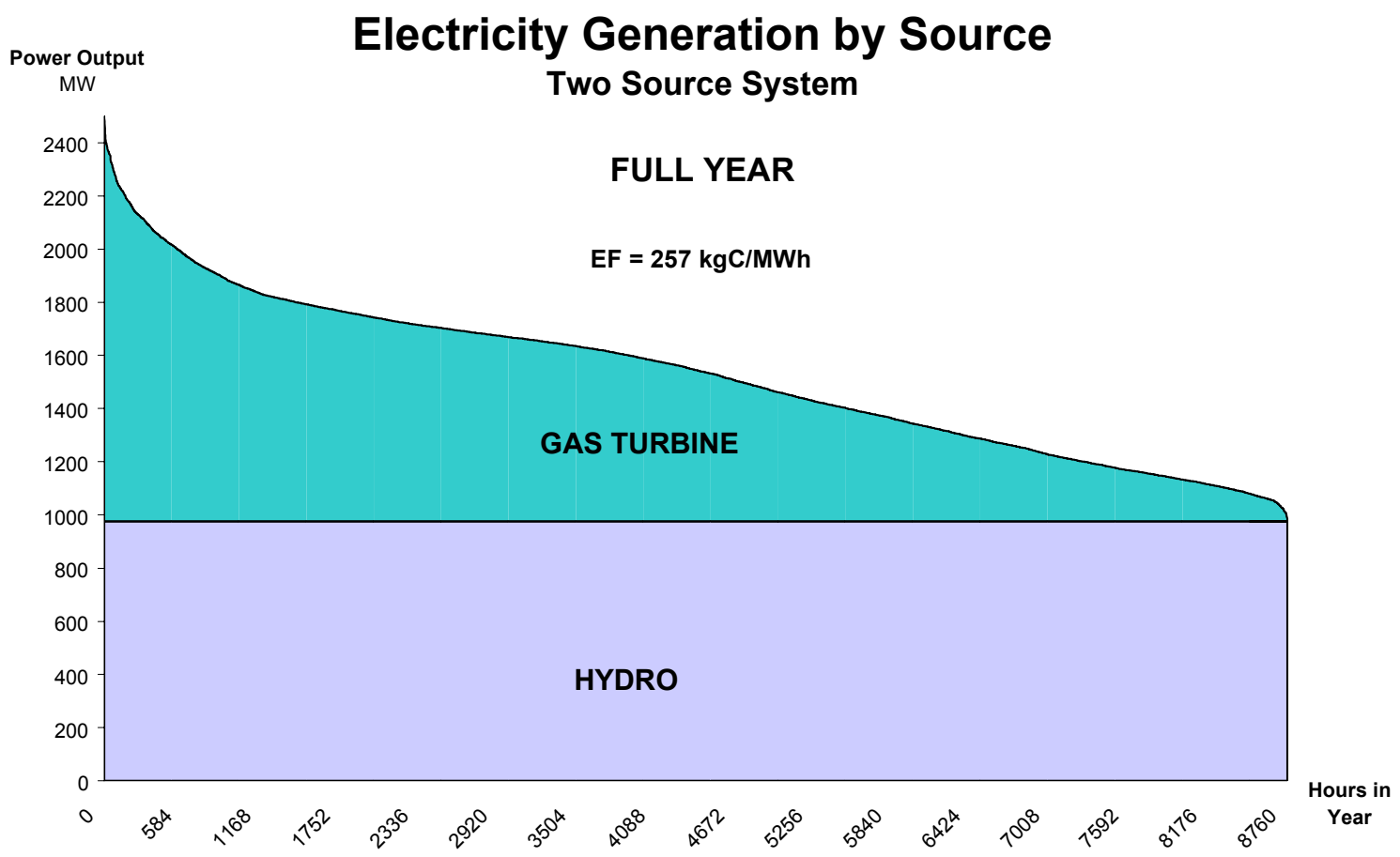

\section{Figure 3}

Plant and Fuel Characteristics

\begin{tabular}{|c|c|c|c|c|c|c|c|}
\hline Type of Plant & Type of Fuel & $\begin{array}{c}\text { Conversion } \\
\text { Efficiency } \\
\% \\
\text { A }\end{array}$ & $\begin{array}{c}\text { Heat } \\
\text { Rate } \\
\mathrm{MJ} / \mathrm{MWh} \\
\mathrm{B}=(1 / \mathrm{A}) * 3.6^{*} 10^{\wedge} 3\end{array}$ & $\begin{array}{c}\text { Carbon Content } \\
\text { (unadjusted) } \\
\text { t C/TJ } \\
\text { C }\end{array}$ & $\begin{array}{c}\text { Combustion } \\
\text { Efficiency } \\
\% \\
\text { D }\end{array}$ & $\begin{array}{c}\text { Carbon Content } \\
\text { (adjusted) } \\
\text { tC/TJ } \\
\text { E }=\mathrm{C} * \mathrm{D}\end{array}$ & $\begin{array}{c}\text { Emissions } \\
\text { Factor per fuel } \\
\mathrm{kgC} / \mathrm{MWh} \\
\mathrm{F}=\mathrm{B}^{*} \mathrm{E} * 10^{\wedge} 3 / 10^{\wedge} 6\end{array}$ \\
\hline Conventional Hydro & & & & & & & 0 \\
\hline Gas Turbine & Heavy Diesel Oil & $28 \%$ & 12857 & 20.2 & 0.99 & 20.0 & 257 \\
\hline Pump Stor. Hydro & & & & & & & 0 \\
\hline
\end{tabular}

AVERAGE OF YEAR AND DRY SEASON

Marginal Power Source Displacement

\begin{tabular}{|l|c|c|c|c|}
\hline & $\begin{array}{c}\text { Hours of Source } \\
\text { being marginal } \\
\text { hours }\end{array}$ & $\begin{array}{c}\text { Share of } \\
\text { Marginal Hours } \\
\%\end{array}$ & $\begin{array}{c}\text { Emissions } \\
\text { Factor } \\
\mathrm{kgC} / \mathrm{MWh}\end{array}$ & $\begin{array}{c}\text { Weighted Emissions } \\
\text { Factor } \\
\mathrm{kgC} / \mathrm{MWh}\end{array}$ \\
\hline Conv. Hydro & 0 & $0 \%$ & 0 & -- \\
\hline Gas Turbine & 8760 and 5856 & $100 \%$ & 257 & -- \\
\hline Sum & 8760 and 5856 & $100 \%$ & & 257 \\
\hline
\end{tabular}




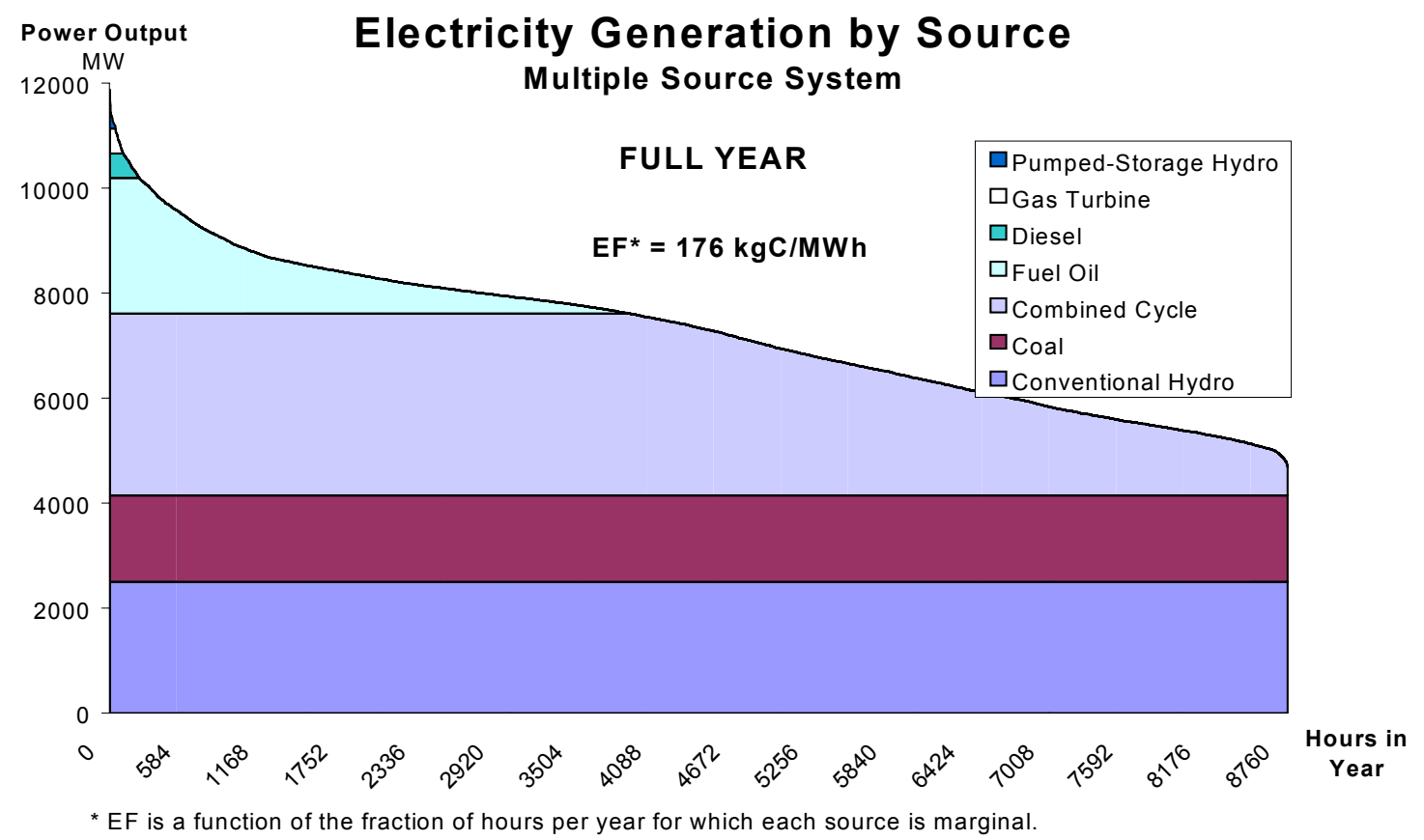

\section{Figure 4}

Plant and Fuel Characteristics

\begin{tabular}{|c|c|c|c|c|c|c|c|}
\hline Type of Plant & Type of Fuel & $\begin{array}{c}\text { Conversion } \\
\text { Efficiency } \\
\% \\
\text { A }\end{array}$ & $\begin{array}{c}\text { Heat } \\
\text { Rate } \\
\mathrm{MJ} / \mathrm{MWh} \\
\mathrm{B}=(1 / \mathrm{A})^{*} 3.6^{*} 10^{\wedge} 3\end{array}$ & $\begin{array}{c}\text { Carbon Content } \\
\text { (unadjusted) } \\
\text { tC/TJ } \\
\text { C }\end{array}$ & $\begin{array}{c}\text { Combustion } \\
\text { Efficiency } \\
\% \\
\text { D }\end{array}$ & $\begin{array}{c}\text { Carbon Content } \\
\text { (adjusted) } \\
\text { tC/TJ } \\
\text { E }=C^{*} \mathrm{D}\end{array}$ & $\begin{array}{c}\text { Emissions } \\
\text { Factor per fuel } \\
\mathrm{kgC} / \mathrm{MWh} \\
\mathrm{F}=\mathrm{B}^{*} \mathrm{E} * 10^{\wedge} 3 / 10^{\wedge} 6\end{array}$ \\
\hline Conventional Hydro & & & & & & & 0 \\
\hline Coal Thermal & Coal & $35 \%$ & 10286 & 25.8 & 0.98 & 25.3 & 260 \\
\hline Combined Cycle & Natural Gas & $40 \%$ & 9000 & 15.3 & 0.995 & 15.2 & 137 \\
\hline Fuel Oil Thermal & Fuel Oil & $32 \%$ & 11250 & 20.2 & 0.99 & 20.0 & 225 \\
\hline Diesel Generation & Heavy Diesel Oil & $25 \%$ & 14400 & 20.2 & 0.99 & 20.0 & 288 \\
\hline Gas Turbine & Heavy Diesel Oil & $28 \%$ & 12857 & 20.2 & 0.99 & 20.0 & 257 \\
\hline Pump Stor. Hydro & & & & & & & 0 \\
\hline
\end{tabular}

Marginal Power Source Displacement

\begin{tabular}{|l|c|c|c|c|}
\hline & $\begin{array}{c}\text { Hours of Source } \\
\text { being marginal } \\
\text { hours }\end{array}$ & $\begin{array}{c}\text { Share of } \\
\text { Marginal Hours } \\
\%\end{array}$ & $\begin{array}{c}\text { Emissions } \\
\text { Factor } \\
\mathrm{kgC} / \mathrm{MWh}\end{array}$ & $\begin{array}{c}\text { Weighted Emissions } \\
\text { Factor } \\
\mathrm{kgC} / \mathrm{MWh}\end{array}$ \\
\hline Conv. Hydro & 0 & $0 \%$ & 0 & 0 \\
\hline Coal Thermal & 0 & $0 \%$ & 260 & 0 \\
\hline Combined Cycle & 4889 & $56 \%$ & 137 & 76 \\
\hline Fuel Oil Thermal & 3650 & $42 \%$ & 225 & 4 \\
\hline Diesel Generation & 117 & $1 \%$ & 288 & 2 \\
\hline Gas Turbine & 58 & $1 \%$ & 257 & 0 \\
\hline Pump Stor. Hydro & 46 & $1 \%$ & 0 & 176 \\
\hline Sum & 8760 & $100 \%$ & & \\
\hline
\end{tabular}




\section{Electricity Generation by Source \\ Two Source System}

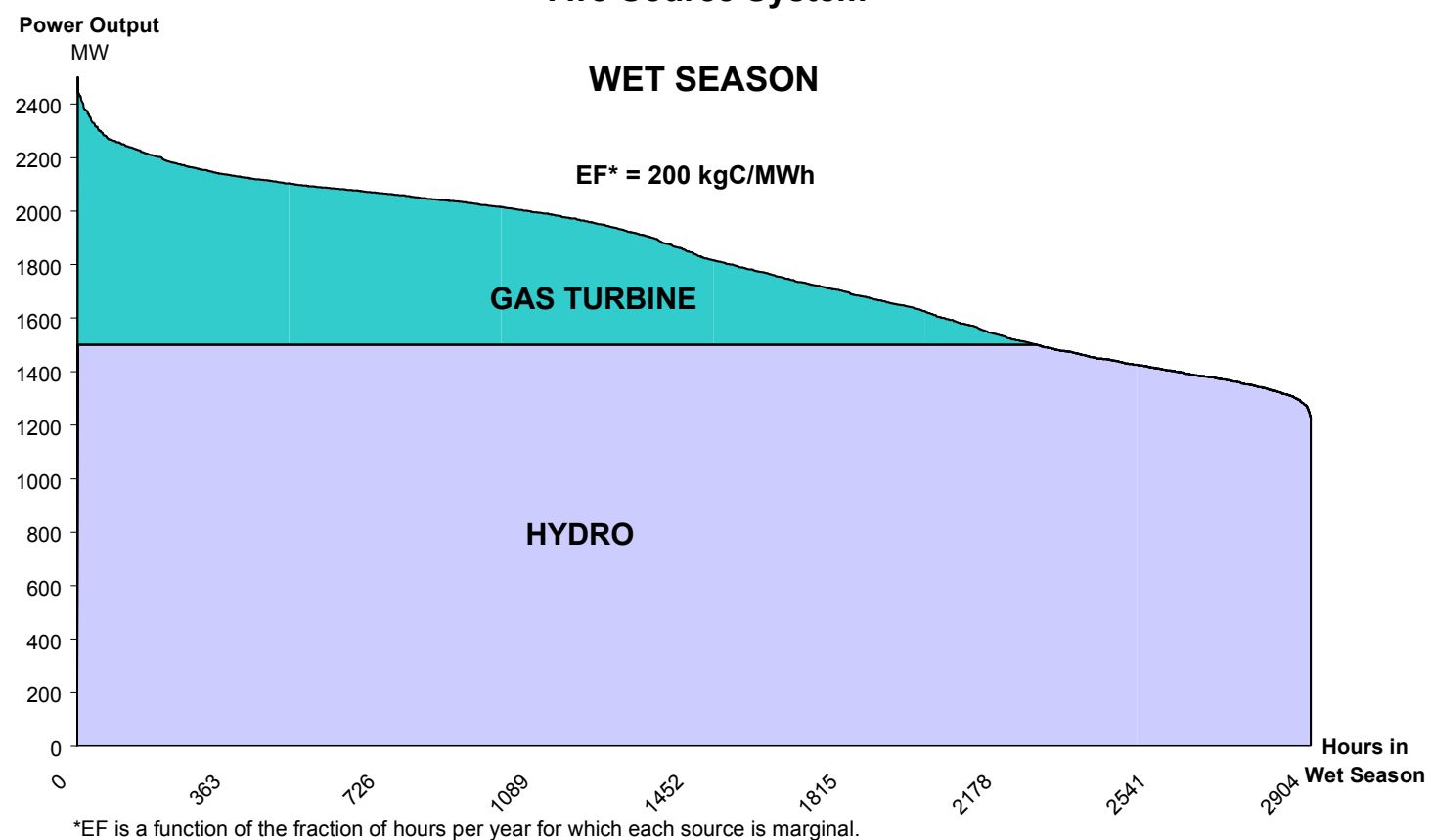

Figure 5

WET SEASON

Marginal Power Source Displacement

\begin{tabular}{|l|c|c|c|c|}
\hline & $\begin{array}{c}\text { Hours of Fuels } \\
\text { being marginal }\end{array}$ & $\begin{array}{c}\text { Share of } \\
\text { Marginal Hours } \\
\%\end{array}$ & $\begin{array}{c}\text { Emissions } \\
\text { Factor } \\
\mathrm{kgC} / \mathrm{MWh}\end{array}$ & $\begin{array}{c}\text { Weighted Emissions } \\
\text { Factor } \\
\mathrm{kgC} / \mathrm{MWh}\end{array}$ \\
\hline Conv. Hydro & 645 & $22 \%$ & 0 & -- \\
\hline Gas Turbine & 2259 & $78 \%$ & 257 & -- \\
\hline Sum & 2904 & $100 \%$ & & 200 \\
\hline
\end{tabular}




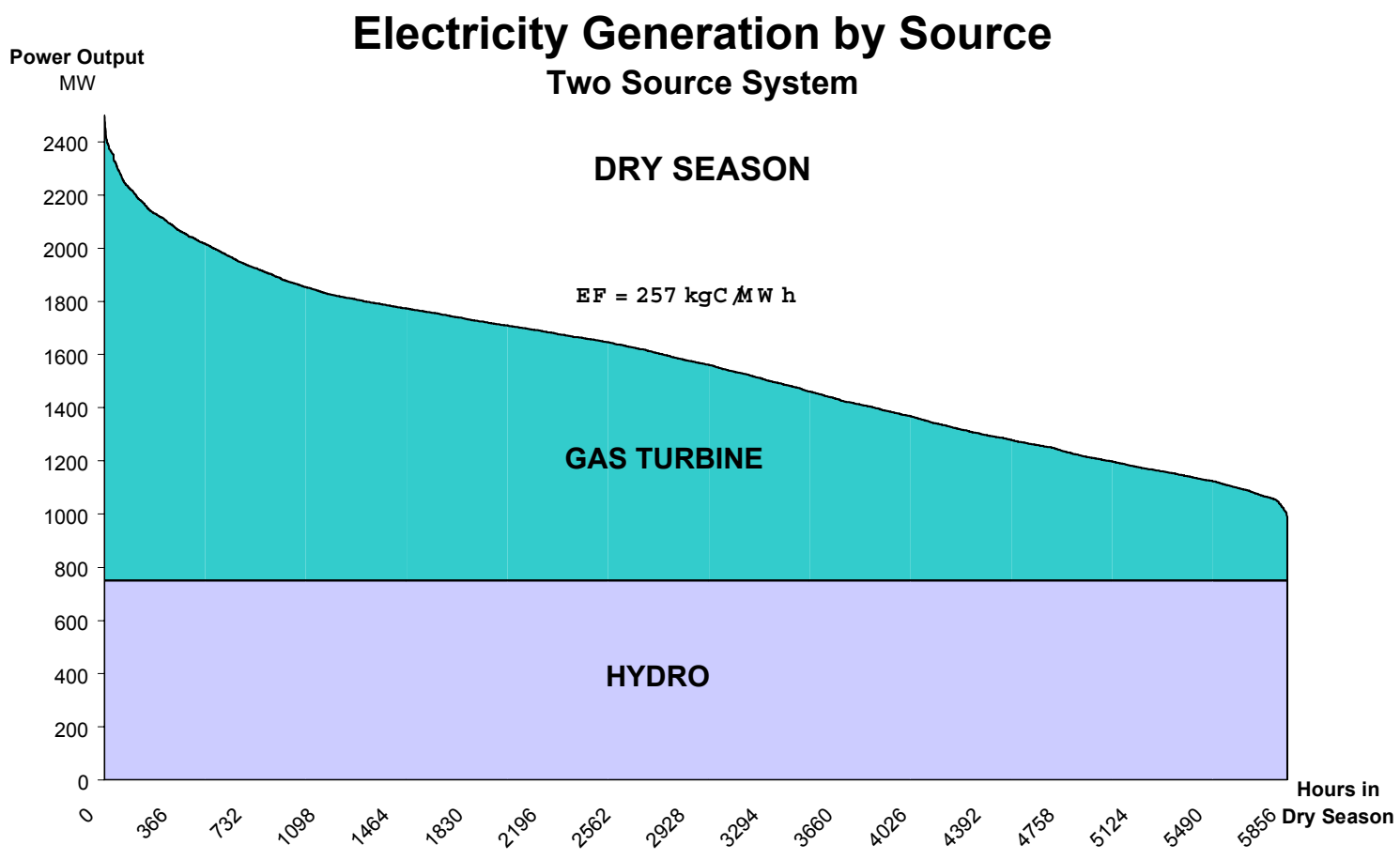

\section{Figure 6}

DRY SEASON

Marginal Power Source Displacement

\begin{tabular}{|l|c|c|c|c|}
\hline & $\begin{array}{c}\text { Hours of Source } \\
\text { being marginal }\end{array}$ & $\begin{array}{c}\text { Share of } \\
\text { Marginal Hours } \\
\%\end{array}$ & $\begin{array}{c}\text { Emissions } \\
\text { Factor } \\
\mathrm{kgC} / \mathrm{MWh}\end{array}$ & $\begin{array}{c}\text { Weighted Emissions } \\
\text { Factor } \\
\mathrm{kgC} / \mathrm{MWh}\end{array}$ \\
\hline Conv. Hydro & 0 & $0 \%$ & 0 & -- \\
\hline Gas Turbine & 5856 & $100 \%$ & 257 & -- \\
\hline Sum & 5856 & $100 \%$ & & 257 \\
\hline
\end{tabular}




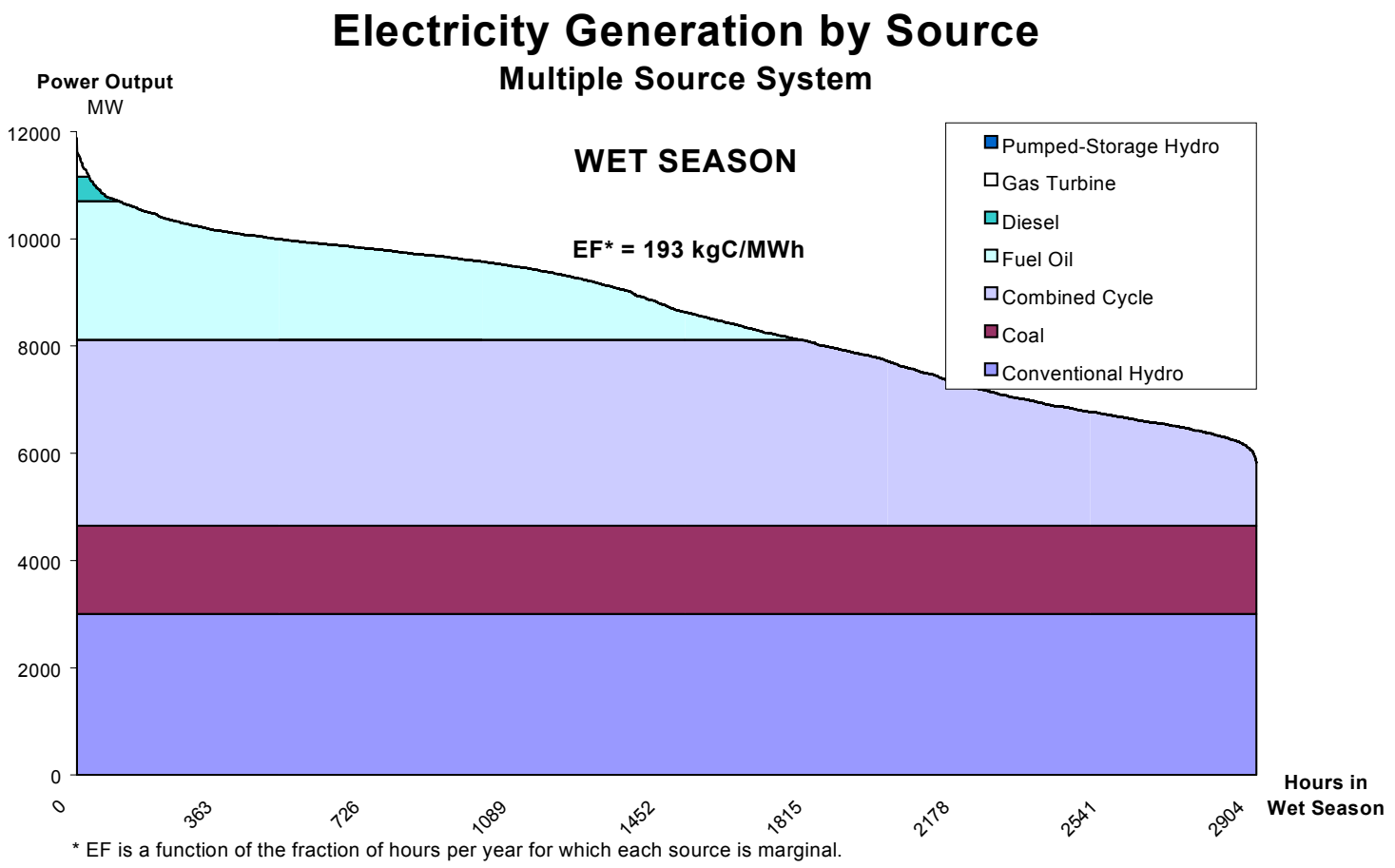

Figure 7

Plant and Fuel Characteristics

\begin{tabular}{|l|l|l|c|c|c|c|c|}
\hline Type of Plant & Type of Fuel & $\begin{array}{c}\text { Conversion } \\
\text { Efficiency } \\
\%\end{array}$ & $\begin{array}{c}\text { Heat } \\
\text { Rate } \\
\mathrm{MJ} / \mathrm{MWh} \\
\mathrm{B}=(1 / \mathrm{A}) * 3.6^{*} 10^{\wedge} 3\end{array}$ & $\begin{array}{c}\text { Carbon Content } \\
\text { (unadjusted) } \\
\mathrm{t} / \mathrm{TJ} \\
\mathrm{C}\end{array}$ & $\begin{array}{c}\text { Combustion } \\
\text { Efficiency } \\
\%\end{array}$ & $\begin{array}{c}\text { Carbon Content } \\
\text { (adjusted) } \\
\mathrm{C} / \mathrm{TJ} \\
\mathrm{E}=\mathrm{C} * \mathrm{D}\end{array}$ & $\begin{array}{c}\text { Emissions } \\
\text { Factor per fuel } \\
\mathrm{kgC} / \mathrm{MWh} \\
\mathrm{F}=\mathrm{B} * \mathrm{E} * 10^{\wedge} 3 / 10^{\wedge} 6\end{array}$ \\
\hline Conventional Hydro & & & & & & & 0 \\
\hline Coal Thermal & Coal & $35 \%$ & 10286 & 25.8 & 0.98 & 25.3 & 260 \\
\hline Combined Cycle & Natural Gas & $40 \%$ & 9000 & 15.3 & 0.995 & 15.2 & 137 \\
\hline Fuel Oil Thermal & Fuel Oil & $32 \%$ & 11250 & 20.2 & 0.99 & 20.0 & 225 \\
\hline Diesel Generation & Heavy Diesel Oil & $25 \%$ & 14400 & 20.2 & 0.99 & 20.0 & 288 \\
\hline Gas Turbine & Heavy Diesel Oil & $28 \%$ & 12857 & 20.2 & 0.99 & 20.0 & 257 \\
\hline Pump Stor. Hydro & & & & & & & \\
\hline
\end{tabular}

Marginal Power Source Displacement

\begin{tabular}{|l|c|c|c|c|}
\hline & $\begin{array}{c}\text { Hours of Source } \\
\text { being marginal } \\
\text { hours }\end{array}$ & $\begin{array}{c}\text { Share of } \\
\text { Marginal Hours } \\
\%\end{array}$ & $\begin{array}{c}\text { Emissions } \\
\text { Factor per fuel } \\
\text { KgC/MWh }\end{array}$ & $\begin{array}{c}\text { Weighted Emissions } \\
\text { Factor } \\
\mathrm{kgC} / \mathrm{MWh}\end{array}$ \\
\hline Conv. Hydro & 0 & $0 \%$ & 0 & 0 \\
\hline Coal Thermal & 0 & $0 \%$ & 260 & 0 \\
\hline Combined Cycle & 119 & $39 \%$ & 137 & 53 \\
\hline Fuel Oil Thermal & 1682 & $58 \%$ & 225 & 730 \\
\hline Diesel Generation & 72 & $2 \%$ & 288 & 3 \\
\hline Gas Turbine & 30 & $1 \%$ & 257 & 0 \\
\hline Pump Stor. Hydro & 1 & $0 \%$ & 0 & 193 \\
\hline Sum & 2904 & $100 \%$ & & \\
\hline
\end{tabular}




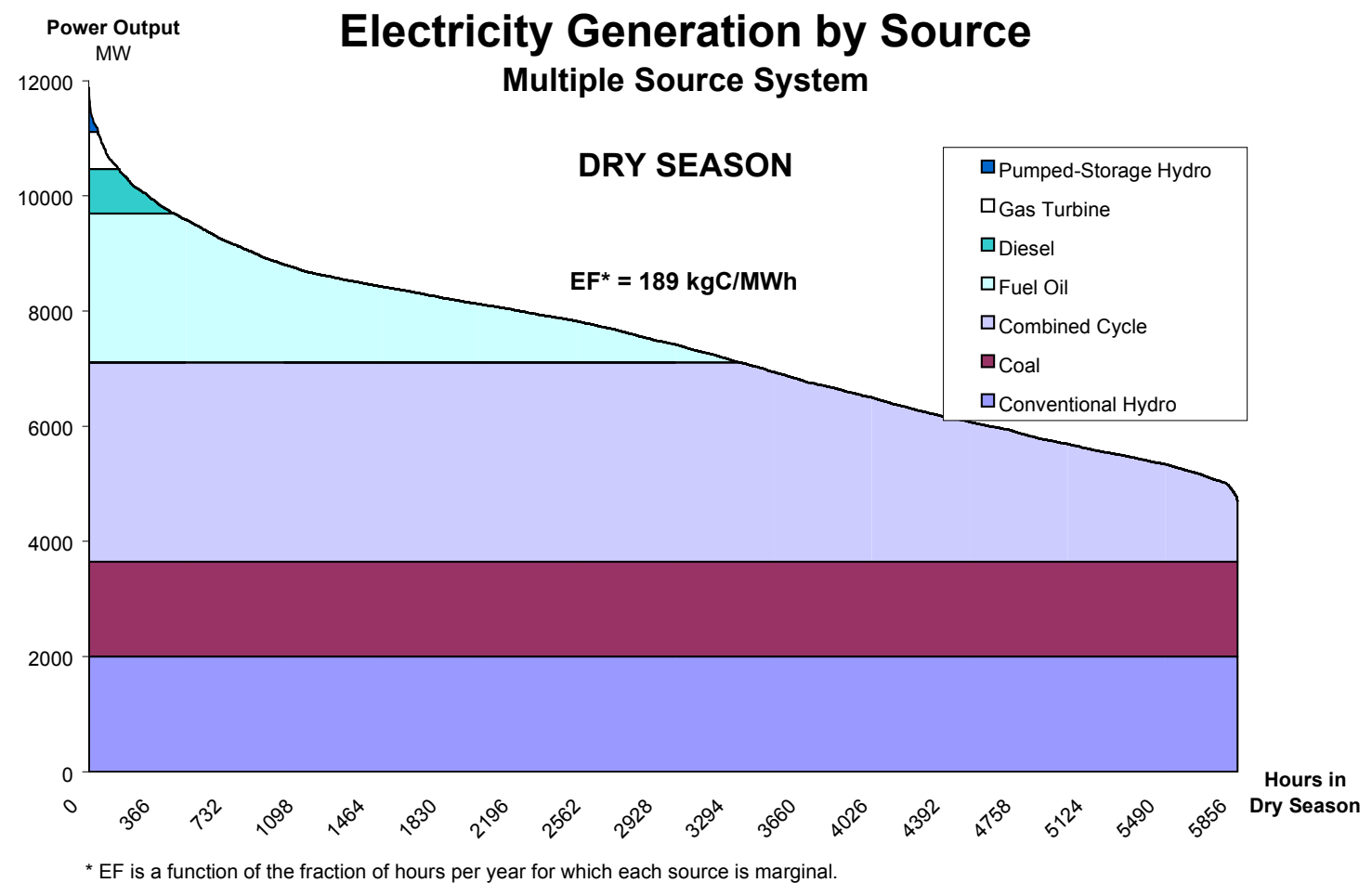

Figure 8

Plant and Fuel Characteristics

\begin{tabular}{|l|l|l|l|l|c|c|c|}
\hline Type of Plant & Type of Fuel & $\begin{array}{c}\text { Conversion } \\
\text { Efficiency } \\
\%\end{array}$ & $\begin{array}{c}\text { Heat } \\
\text { Rate } \\
\mathrm{MJ} / \mathrm{MWh} \\
\mathrm{B}=(1 / \mathrm{A}) * 3.6^{*} 10^{\wedge} 3\end{array}$ & $\begin{array}{c}\text { Carbon Content } \\
\text { (unadjusted) } \\
\mathrm{tC} / \mathrm{TJ} \\
\mathrm{C}\end{array}$ & $\begin{array}{c}\text { Combustion } \\
\text { Efficiency } \\
\%\end{array}$ & $\begin{array}{c}\text { Carbon Content } \\
\text { (adjusted) } \\
\mathrm{tC} / \mathrm{TJ} \\
\mathrm{E}=\mathrm{C} * \mathrm{D}\end{array}$ & $\begin{array}{c}\text { Emissions } \\
\text { Factor per fuel } \\
\mathrm{kgC} / \mathrm{MWh} \\
\mathrm{F}=\mathrm{B}^{*} \mathrm{E} * 10^{\wedge} 3 / 10^{\wedge} 6\end{array}$ \\
\hline Conventional Hydro & & & & & & & 0 \\
\hline Coal Thermal & Coal & $35 \%$ & 10286 & 25.8 & 0.98 & 25.3 & 260 \\
\hline Combined Cycle & Natural Gas & $40 \%$ & 9000 & 15.3 & 0.995 & 15.2 & 137 \\
\hline Fuel Oil Thermal & Fuel Oil & $32 \%$ & 11250 & 20.2 & 0.99 & 20.0 & 225 \\
\hline Diesel Generation & Heavy Diesel Oil & $25 \%$ & 14400 & 20.2 & 0.99 & 20.0 & 288 \\
\hline Gas Turbine & Heavy Diesel Oil & $28 \%$ & 12857 & 20.2 & 0.99 & 20.0 & 257 \\
\hline Pump Stor. Hydro & & & & & & & \\
\hline
\end{tabular}

Marginal Power Source Displacement

\begin{tabular}{|l|c|c|c|c|}
\hline & $\begin{array}{c}\text { Hours of Source } \\
\text { being marginal }\end{array}$ & $\begin{array}{c}\text { Share of } \\
\text { Marginal Hours } \\
\%\end{array}$ & $\begin{array}{c}\text { Emissions } \\
\text { Factor per fuel } \\
\mathrm{kgC} / \mathrm{MWh}\end{array}$ & $\begin{array}{c}\text { Weighted Emissions } \\
\text { Factor } \\
\mathrm{kgC} / \mathrm{MWh}\end{array}$ \\
\hline Conv. Hydro & 0 & $0 \%$ & 0 & 0 \\
\hline Coal Thermal & 0 & $0 \%$ & 260 & 0 \\
\hline Combined Cycle & 2541 & $43 \%$ & 137 & 59 \\
\hline Fuel Oil Thermal & 2878 & $49 \%$ & 225 & 111 \\
\hline Diesel Generation & 287 & $5 \%$ & 288 & 5 \\
\hline Gas Turbine & 103 & $2 \%$ & 257 & 0 \\
\hline Pump Stor. Hydro & 47 & $1 \%$ & 0 & 189 \\
\hline Sum & 5856 & $100 \%$ & & 14 \\
\hline
\end{tabular}

